\title{
Environmental Flow Assessment in a Lotic Ecosystem of Central Western Ghats, India
}

\section{Ramachandra TV*, Vinay S and Bharath H Aithal}

Energy and Wetlands Research Group, CES TE15, Centre for Ecological Sciences, Indian Institute of Science, Bangalore, Karnataka, India

*Corresponding author: Ramachandra TV, Energy and Wetlands Research Group, CES TE15, Centre for Ecological Sciences, Indian Institute of Science, Bangalore, Karnataka, India, Tel: 08022933099/22933503; E-mail: cestvr@ces.iisc.ernet.in

Rec date: Apr 28, 2016; Acc date: June 09, 2016; Pub date: June 25, 2016

Copyright: () 2016 Ramchandra TV, et al. This is an open-access article distributed under the terms of the Creative Commons Attribution License, which permits unrestricted use, distribution, and reproduction in any medium, provided the original author and source are credited.

\begin{abstract}
Environmental/Ecological flow refers to the minimum flow of water to be maintained in a water body (river, lake, etc.) to sustain ecosystem services. Understanding environmental flow is important to ensure the local ecological and social (people, agriculture and horticulture, etc.) needs in a sustained and balanced way, while designing large scale projects (such as hydro-electric, river diversion, etc.). Western Ghats are the mountain ranges extending from southern tip of India (Tamil Nadu-Kanyakumari) to Gujarat. These mountain ranges are rich in biodiversity with diverse and endemic flora and fauna, and is birth place to numerous perennial rivers namely Netravathi, Sita, Sharavathi, Aghanashini, Krishna, Cauvery, etc. Western Ghats is often referred as water tower of peninsular India, due to the water and food security provided by the ecosystem through array of services. The region is also one among 35 global biodiversity hotspots. However, deforestation due to large scale land cover changes has affected the water sustenance in the region evident from the quantity and duration of water availability during post monsoon period. Forests in the Western Ghats along with the soil characteristics and precipitation plays a major role in storing water in sub-surface (vadoze and groundwater) zones during monsoon, and releases to the streams during post monsoon periods catering to the needs of the dependent biota including humans. Some of these undisturbed/ unaltered natural flow conditions in rivers and streams have proved their worth with the presence of rich and diverse species and array of ecosystem services, which also has helped in sustaining the livelihood of dependent populations. The undisturbed flow conditions guarantees the natural flow as well as minimum flow in streams to sustain the ecosystem services, which helps in meeting the social and ecological needs. Growing demand to cater the demands of burgeoning human population coupled with accelerated pace of deforestation due to unplanned and senseless developmental projects in the ecologically fragile regions have led the water scarcity even in regions receiving high amount of rainfall. In the current communication an attempt is made to understand the linkages between the hydrological dynamics across varied landscape with the anthropogenic and ecological water needs. If the available water resource meets the societal and environmental demands across seasons, the catchment is said to achieve the minimum flow requirements. The federal government has plans to divert the water from rivers in Western Ghats region to the dry arid regions in Karnataka. In this regard, environmental flow assessment of Yettinaholé river in Central Western Ghats is carried out to understand the feasibility of river diversion through the assessment of hydrologic regime with the analysis of land use dynamics (using remote sensing data), meteorological data (rainfall, temperature, etc. from IMD, Pune), hydrological data (from gauged streams) apart from field investigations in the catchment. The catchments receive annual rainfall of 3000-5000 mm (Department of Statistics, Government of Karnataka). Land use analyses reveal that Major portion of the catchment is covered with evergreen forest $(45.08 \%)$ followed by agriculture plantations $(29.05 \%)$ and grass lands $(24.06 \%)$. Water yield in the catchment computed for each of sub-catchments based on the current land use and other related hydrological parameters using empirical method. The total runoff yield from the catchments is estimated to be $9.55 \mathrm{TMC}$. About 5.84 TMC is required for domestic purposes including agriculture, horticulture and livestock rearing. The quantum of water required to sustain fish life in the streams is about 2 TMC, computed based on hydrological discharge monitoring and fish diversity in streams during 18 months (covering all seasons) in select streams in Western Ghats. Considering the available water is sufficient only to meet the anthropogenic and ecological needs in the region, the sustainable option to meet the water requirements in dry arid regions would be through (i) decentralized water harvesting (through tanks, ponds, lakes, etc.), (ii) rejuvenation or restoration of existing lakes/ponds, (iii) reuse of waste water, (iv) recharging groundwater resources, (v) planting native species of grasses and tree species in the catchment (to enhance percolation of water in the catchment), (vi) implementation of soil and water conservation through micro-watershed approaches. Implementation of these location specific approaches in arid regions would cost much less compared to the river diversion projects, which if implemented would help the section of the society involved in decision making, construction and implementation of the project.
\end{abstract}

Keywords: Ecological flow; Yettinaholé River; Watershed; Land Introduction cover; Fresh water ecosystem

The Western Ghats is a series of hills located in the western part of peninsular India stretching over a distance of $1,600 \mathrm{~km}$ from north to south and covering an area of about 1,60,000 sq.km and one among the 
Citation: Ramachandra TV, Vinay S, Bharath HA (2016) Environmental Flow Assessment in a Lotic Ecosystem of Central Western Ghats, India. Hydrol Current Res 7: 248. doi:10.4172/2157-7587.1000248

Page 2 of 14

35 global hotspots of biodiversity [1-3]. It harbors very rich and rare flora and fauna and there are records of over 4,500 species of flowering plants with $38 \%$ endemics, 330 butterflies with $11 \%$ endemics, 156 reptiles with $62 \%$ endemics, 508 birds with $4 \%$ endemics, 120 mammals with $12 \%$ endemics, 289 fishes with $41 \%$ endemics and 135 amphibians with $75 \%$ endemics [4-7].

Western Ghats has numerous watersheds that feed perennial rivers of peninsular India [2]. It encompasses series of west and east flowing rivers that originates from the Western Ghats, supporting as source of sustenance for existing life forms in the environment. One such source of perennial waters is Yettinaholé originating at an altitude of $950 \mathrm{~m}$ in Sakaleshpura taluk of Hassan district, and tributary of river Gundia, which joins Kumaradhara and finally drains to Netravathi River The region with a repository of endemic and rare biodiversity is ecologically sensitive and large scale degradation of catchment landscape have influenced the availability of water and has also affected the sustenance of biodiversity. Changes in landscape structure and the regional climate $[8,9]$ have altered the hydrologic regime $[10,11]$ in many lotic ecosystems in the tropical regions, affecting the potential of the catchment to retain water in the surface and sub surfaces. Various studies carried out in Western Ghats [12-14] and across the globe show the relevance of landscape on surface and subsurface hydrological regime [12-19]. Few studies carried out in Western Ghats also emphasize on the role of hydrological regime on the habitats, ecology, biodiversity, quality of water, soil and ecosystem etc. [20-23]. In the current communication an attempt has been made to understand the linkages between the hydrological dynamics across varied landscape of Yettinaholé catchment with the societal and environmental water needs. In this regard, the study investigates land use dynamics, hydrological yield, fish diversity in select streams and linkages with the flow during lean season and drivers of hydrological regime impairment.

\section{Materials and Methods}

\section{Study area}

Yettinaholé catchment has a pristine ecosystem with rich biodiversity (Figure 1 and Table 1), extend from $12044^{\prime} \mathrm{N}$ to $12058^{\prime} \mathrm{N}$ Latitude and 75037'E to 75047'E longitude encompassing total area of $179.68 \mathrm{~km}^{2}$. The terrain (Figure 2) is undulating with altitude varying from $666 \mathrm{~m}$ above MSL to $1292 \mathrm{~m}$ above MSL leading to higher density of stream network (Figure 3). Geologically, rock types consist of Gneiss, the soils are loamy ranging from sandy loamy to clay loamy. Soils (Figure 4) in the region are fertile and highly permeable, hence allowing the precipitated water to percolate easily into the subsurface recharging ground water and storing water in the sub surfaces and hence keeping the water source perennial to the catchment and the downstream users during and post monsoon.

Decadal population in Sakleshpura Taluk (spatial extent 1034 sq. $\mathrm{km}$ ) of Hassan district is given in Figure 5 and Table 2 shows a declining trend due to migration to cities during post 2001. Population dynamics of the catchments also follows the dynamics of Sakleshpura taluk. Total Population of all the catchments with respect to census data [24,25] was estimated as 17005 in 2001, has declined to 16345 in 2011 at a decadal rate of $3.88 \%$. Population for the year 2014 was calculated as 16156 based on the temporal data. Population density for each of the sub catchments are as depicted in Figure 6 and Table 3.

\begin{tabular}{|l|l|l|}
\hline Sub basin id & Stream Name & Area $(\mathrm{Ha})$ \\
\hline 1 & Yettinaholé & 4878.7 \\
\hline 2 & Yettinaholé T2 & 781.1 \\
\hline 3 & Yettinaholé T1 & 991.1 \\
\hline 4 & Kadumane holé 2 & 761.4 \\
\hline 5 & Kadumane holé 1 & 1362.4 \\
\hline 6 & Hongada halla & 5676.6 \\
\hline 7 & Keri holé & 2198.3 \\
\hline 8 & Yettinaholé lower reach & 1319.1 \\
\hline
\end{tabular}

Table 1: Study Area.

\begin{tabular}{|l|l|l|l|l|l|}
\hline Census Year & 1921 & 1931 & 1941 & 1951 & 1961 \\
\hline Population & 44115 & 44300 & 43765 & 53398 & 77522 \\
\hline Census Year & 1971 & 1981 & 1991 & 2001 & 2011 \\
\hline Population & 91175 & 114008 & 124753 & 133657 & 128633 \\
\hline
\end{tabular}

Table 2: Population Growth of Sakleshpura Taluk [24,25].

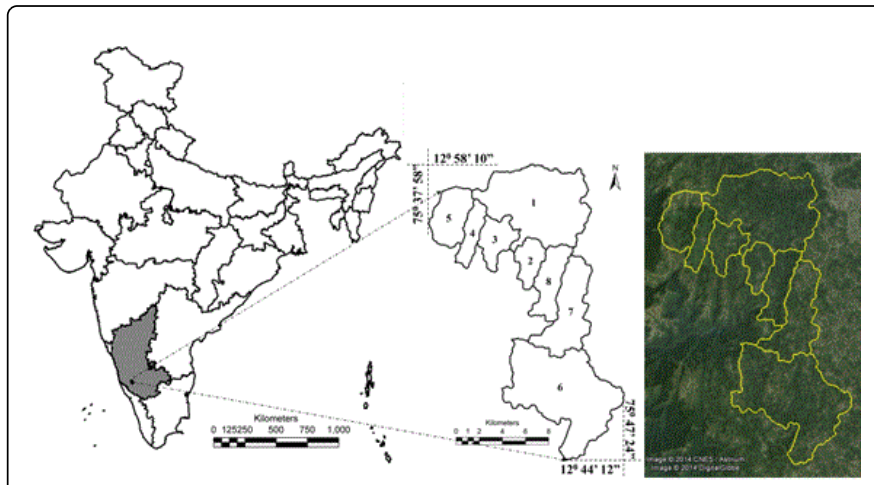

Figure 1: Study Area-Yettinaholé catchment, Karnataka, India.

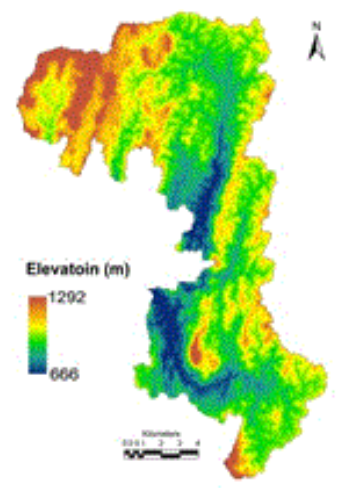

Figure 2: Digital Elevation Model. 
Citation: Ramachandra TV, Vinay S, Bharath HA (2016) Environmental Flow Assessment in a Lotic Ecosystem of Central Western Ghats, India. Hydrol Current Res 7: 248. doi:10.4172/2157-7587.1000248

Page 3 of 14
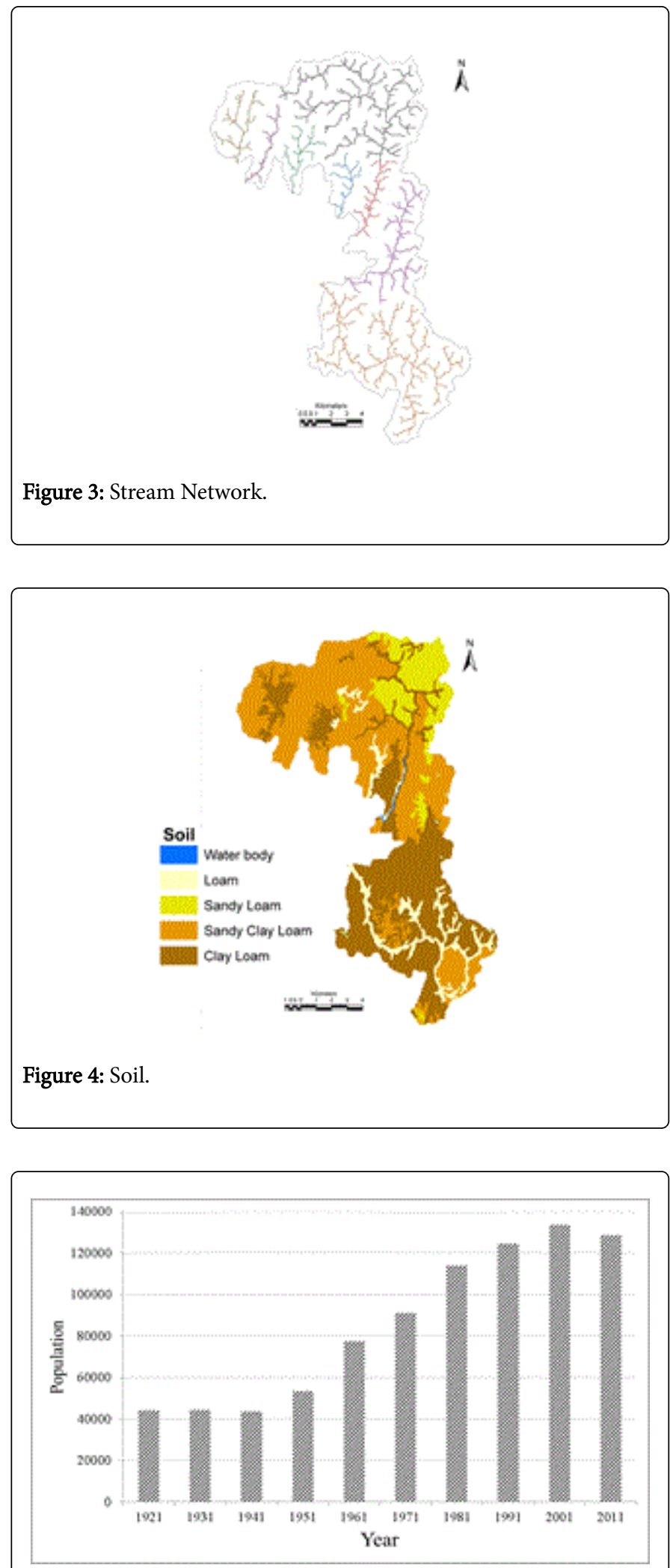

Figure 5: Population Growth of Sakleshpura Taluk.

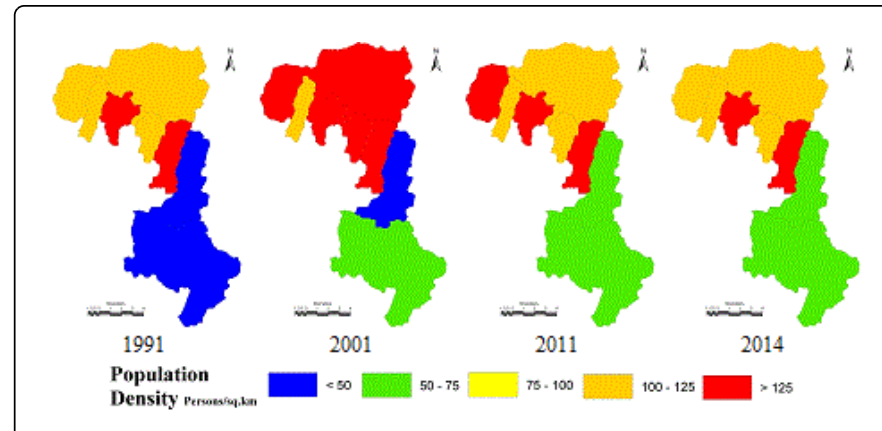

Figure 6: Population Density in Sub Catchments.

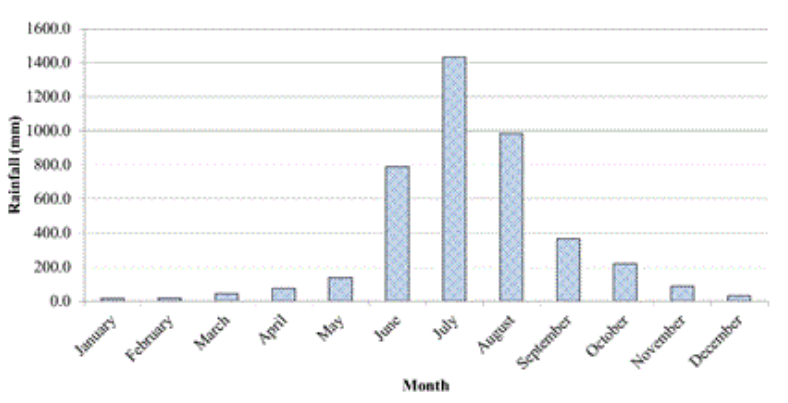

Figure 7: Rainfall in $\mathrm{mm}$.

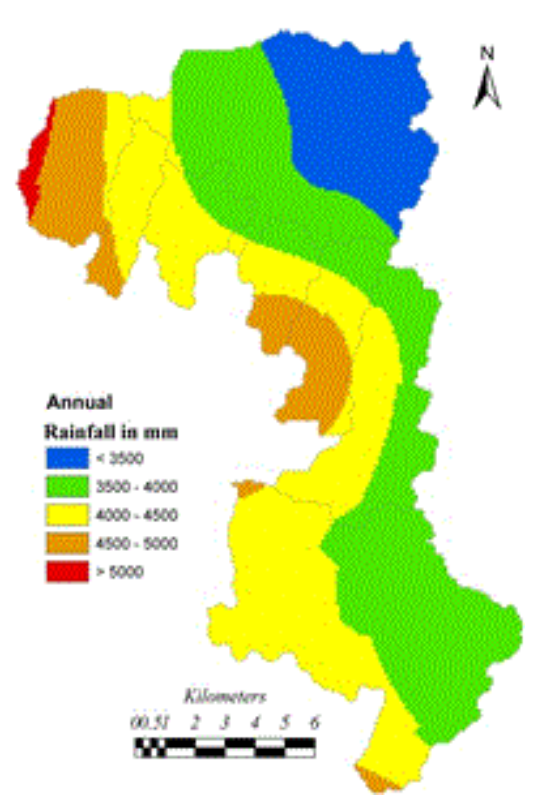

Figure 8: Rainfall distribution. 


\begin{tabular}{|l|l|l|l|l|l|}
\hline $\begin{array}{l}\text { Sub Basin } \\
\text { Id }\end{array}$ & Sub basin & $\mathbf{1 9 9 1}$ & $\mathbf{2 0 0 1}$ & $\mathbf{2 0 1 1}$ & $\mathbf{2 0 1 4}$ \\
\hline 1 & Yettina holé & 117.86 & 126.92 & 122 & 120.59 \\
\hline 2 & Yettina holé T2 & 116.12 & 125.08 & 120.22 & 118.81 \\
\hline 3 & Yettina holé T1 & 126.52 & 136.31 & 130.96 & 129.45 \\
\hline 4 & Kadumane holé 2 & 108.36 & 116.76 & 112.17 & 110.98 \\
\hline 5 & Kadumane holé 1 & 121.33 & 130.65 & 125.58 & 124.12 \\
\hline 6 & Hongadahalla & 47.26 & 50.89 & 48.92 & 48.36 \\
\hline 7 & Keri holé & 32.71 & 35.25 & 33.89 & 33.48 \\
\hline 8 & Yettina holé lower reach & 151.46 & 163.14 & 156.85 & 155.03 \\
\hline
\end{tabular}

Table 3: Population density (persons per sq. km).

The region receives an annual rainfall of 3500 to $5000 \mathrm{~mm}$ across the catchment. Precipitation in the catchment during June to September is due to the southwest monsoons, with July having maximum rainfall over $1300 \mathrm{~mm}$. Monthly variation in rainfall is depicted in Figure 7. Spatial variation of rainfall across the catchments was assessed based on 110 years data [26] (1901 to 2010) from the rain gauge stations in and around the catchment (Figure 8). Figure 9 depicts monthly temperatures [27] variations, which ranges from $14.7^{\circ} \mathrm{C}$ (January) to $31.6^{\circ} \mathrm{C}$ (in March).

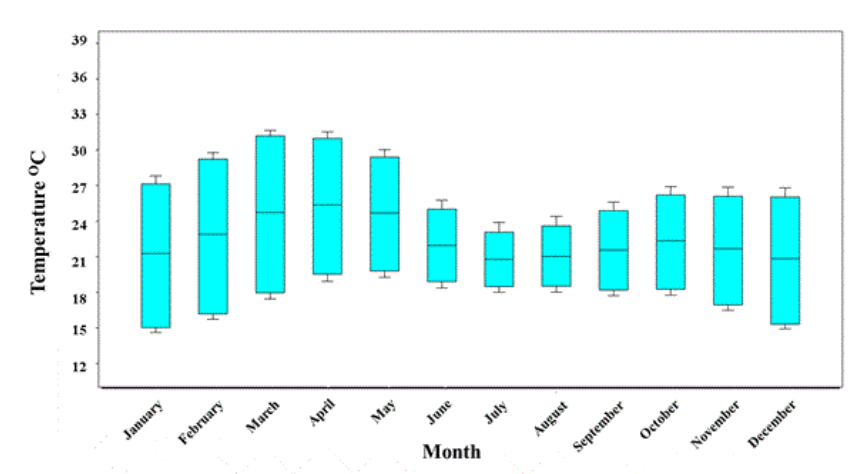

Figure 9: Monthly temperature variations.

\section{Data}

Data required for hydrological and land use analyses were (i) social and demographic data from the government agencies, (ii) temporal remote sensing data from public archive and (iii) primary data through field investigations. Latest remote sensing data used is of Landsat 8 series (2014). Rainfall data was acquired from the Directorate of Economics and Statistics, Government of Karnataka [26], Temperature data was sourced from World Clim-Global Climate Data [27] of $1 \mathrm{~km}$ resolution. Census data collected from government of India, state and district census departments $[24,25]$. These data was supplemented with secondary data compiled from various sources as tabulated in Table 4. Primary data is compiled through field investigations and through structured questionnaire (household survey).

\section{Method}

The method for the evaluation of the environmental flow and hydrological status is given in Figure 10. Hydrologic assessment in the catchment involved 1) delineation of catchment boundary 2) land use analysis, 3) assessment of the hydro meteorological data, 4) analysis of population census data, 5) compilation of data through public interactions for assessing the water needs for livestock, agriculture/ horticulture and cropping pattern, and 6) evaluation of hydrologic regime.

Delineation of catchment boundary: Catchment boundaries (Figure 1) and the stream networks (Figure 3) were delineated considering the topography of the terrain based on CartoSat DEM using the QSWAT module-Quantum GIS 2.1032 bit. These catchment boundaries were overlaid on the extracted boundaries from the Survey of India topographic maps for validations. Corrected catchment boundaries were further overlaid on Google earth in order to visualize the terrain variations (Figure 2).

\begin{tabular}{|c|c|c|}
\hline Data & Description & Source \\
\hline Remote sensing data-spatial data & $\begin{array}{l}\text { Remote sensing data of } 30 \mathrm{~m} \text { spatial resolution and } 16 \text { bit } \\
\text { radiometric resolution were used to analyse land uses at } \\
\text { catchment levels. }\end{array}$ & [28] \\
\hline Rainfall & $\begin{array}{l}\text { Daily rainfall data of } 110 \text { years }(1901-2010) \text {, to assess the trends in } \\
\text { rainfall distribution and variability across basins. }\end{array}$ & {$[26,29]$} \\
\hline Crop Calendar & $\begin{array}{l}\text { To estimate the crop water requirements based on the growth } \\
\text { phases }\end{array}$ & [30-35] \\
\hline Crop Coefficient & $\begin{array}{l}\text { Evaporative coefficients used to estimate the actual } \\
\text { evapotranspiration. }\end{array}$ & {$[33,36]$} \\
\hline $\begin{array}{l}\text { Temperature (max, min, mean), } \\
\text { Extraterrestrial solar radiation }\end{array}$ & $\begin{array}{l}\text { Monthly temperature data ( } 1 \mathrm{~km} \text { spatial resolution) and monthly } \\
\text { extra-terrestrial solar radiation (Every } 1^{\circ} \text { North latitude) available }\end{array}$ & {$[27,36-38]$} \\
\hline
\end{tabular}




\begin{tabular}{|c|c|c|}
\hline & $\begin{array}{l}\text { across different hemispheres to estimate the potential } \\
\text { evapotranspiration. }\end{array}$ & \\
\hline Population data & $\begin{array}{l}\text { Population census data available at village level }(2001,2011) \text {, used } \\
\text { to estimate the population at sub basin level for the year } 2014 \text {, and } \\
\text { estimate the water requirement for domestic use at sub basin } \\
\text { levels. }\end{array}$ & {$[24,25]$} \\
\hline Livestock Census & $\begin{array}{l}\text { Taluk level data was used to estimate the livestock population and } \\
\text { estimate water requirement at each of the river basins. }\end{array}$ & [39] \\
\hline Digital Elevation data & $\begin{array}{l}\text { Carto-DEM of } 30 \mathrm{~m} \text { resolution in association with Google earth and } \\
\text { the Survey of India-Topographic maps }(1: 50000) \text { was used to } \\
\text { delineate the catchment boundaries, stream networks, contours, } \\
\text { etc. }\end{array}$ & [40] \\
\hline Secondary Data & $\begin{array}{l}\text { Collateral data from government agencies regarding agriculture, } \\
\text { horticulture, forests, soil, etc. for land use classification, delineation } \\
\text { of streams/rivers/catchment, geometric correction (Remote sensing } \\
\text { data). }\end{array}$ & {$[40-44]$} \\
\hline Field data & $\begin{array}{l}\text { Geometric Corrections, training data for land use classification, } \\
\text { crop water requirement, livestock water requirement, etc. }\end{array}$ & $\begin{array}{l}\text { GPS based field data, data form public (stratified random } \\
\text { sampling of households) }\end{array}$ \\
\hline Flow data & $\begin{array}{l}\text { Evaluation of minimum flow requirements to sustain ecology (fish, } \\
\text { etc.) and downstream dependent population's livelihood }\end{array}$ & $\begin{array}{l}\text { Flow measurements at Hongadahalla, Kadumanehalla, } \\
\text { and select streams of Sharavathi river }[45,46]\end{array}$ \\
\hline Fish diversity & $\begin{array}{l}\text { Understanding fish ecology in relation to water quantity and } \\
\text { duration of flow to determine EF }\end{array}$ & $\begin{array}{l}\text { Selected stream catchments and dams Sharavathi river } \\
\text { [47] }\end{array}$ \\
\hline
\end{tabular}

Table 4: Data used for land use and assessment of hydrologic regime.

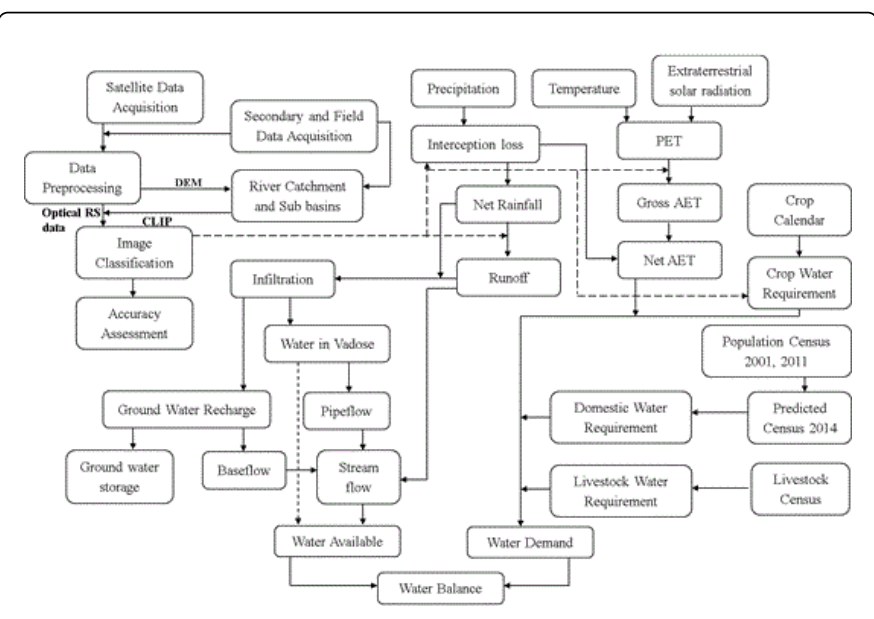

Figure 10: Method for computing environmental flow based on hydrologic variables.

Land use assessment: Large scale land-use land-cover (LULC) changes leading to deforestation is one of the drivers of global climate changes and alteration of biogeochemical cycles. This has given momentum to investigate the causes and consequences of LULC by mapping and modelling landscape patterns and dynamics and evaluating these in the context of human-environment interactions in the riverine landscapes. Human induced environmental changes and consequences are not uniformly distributed over the earth. However their impacts threaten the sustenance of human-environmental relationships. Land cover refers to physical cover and biophysical state of the earth's surface and immediate subsurface and is confined to describe vegetation and manmade features. Thus, land cover reflects the visible evidence of land cover of vegetation and non-vegetation. Land use refers to use of the land surface through modifications by humans and natural phenomena. Heterogeneous terrain in the landscape with the interacting ecosystems is characterized by its dynamics. Human induced land use and land cover (LULC) changes have been the major driver of the landscape dynamics at local levels. Land use assessment was carried using the maximum likelihood classification technique $[48,49]$. Understanding of landscape dynamics helps in the sustainable management of natural resources.

Land use analysis involved i) generation of FCC-False Colour Composite (Figure 11) of remote sensing data (bands-green, red and NIR). This helped in locating heterogeneous patches in the landscape ii) selection of training polygons (these correspond to heterogeneous patches in FCC) covering $15 \%$ of the study area and uniformly distributed over the entire study area, iii) loading these training polygons co-ordinates into pre-calibrated GPS, vi) collection of the corresponding attribute data (land use types) for these polygons from the field. GPS helped in locating respective training polygons in the field, iv) supplementing this information with Google Earth v) $65 \%$ of the training data has been used for classification, while the balance is used for validation or accuracy assessment.

Land uses were categorized into 8 classes namely. i) water bodies (lakes/tanks, rivers, streams, ii) built up (buildings, roads or any paved surface, iii) open spaces iv) evergreen forest (evergreen and semi evergreen), v) deciduous forest (Moist deciduous and dry deciduous) vi) scrub land and grass lands, vii) agriculture, (viii) private plantations (coconut, arecanut, rubber) and forest plantations (Acacia, Teak, etc.)

Assessment of the hydro meteorological data: This involved assessment of the spatial and temporal variations in rainfall $[26,29,50]$ in and around the study region. Long term precipitation data helped in understanding the rainfall variability over decades. Along with rainfall, 
Citation: Ramachandra TV, Vinay S, Bharath HA (2016) Environmental Flow Assessment in a Lotic Ecosystem of Central Western Ghats, India.

Page 6 of 14

temperature (minimum, maximum and average), extra-terrestrial solar radiation across the catchment were used to hydrological behaviors of the catchments which enables to understand the hydrological status.

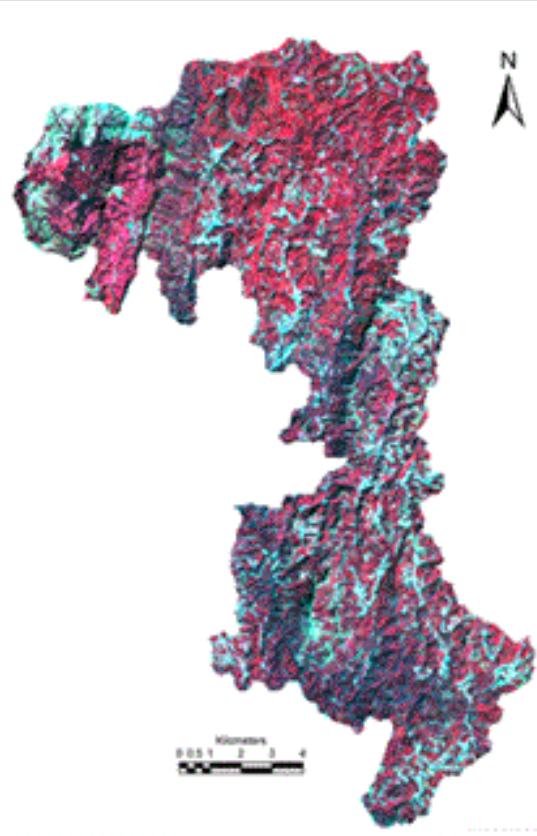

Figure 11: False Colour Composite of Study area.

Rainfall: Point data of daily rainfall from rain gauge stations for the period 1901-2010 [26,29,50] were used for the analysis. Some rain gauge stations had incomplete records with missing data for few months. The average monthly and annual rainfall data were used to derive rainfall map throughout the study area and was used to derive the gross yield (RG) in the basin (equation 1). Net yield (RN) was quantified (equation 2) as the difference between gross rainfall and interception (In).

$$
\begin{aligned}
& \mathrm{RG}=\mathrm{A} \times \mathrm{P} \ldots \ldots .(1) \\
& \mathrm{RN}=\mathrm{RG}-\mathrm{In} \ldots \ldots(2)
\end{aligned}
$$

Where, RG: Gross rainfall yield volume; A: Area in Hectares; P: Precipitation in $\mathrm{mm}, \mathrm{RN}$ : Net rainfall yield volume; and In: Interception volume

InterceptionDuring monsoons, portion of rainfall does not reach the surface of the earth; it remains on the canopy of trees, roof tops, etc. and gets evaporated. Field studies in Western Ghats show that, losses due to interception is about $15 \%$ to $30 \%$, based on the canopy cover. Table 5 shows the interception loss across various rainy months and land uses.

\begin{tabular}{|l|l|l|}
\hline Vegetation types & Period & Interception \\
\hline Evergreen/semi evergreen forests & June-October & $\mathrm{I}=5.5+0.30(\mathrm{P})$ \\
\hline Moist deciduous forests & June-October & $\mathrm{I}=5.0+0.30(\mathrm{P})$ \\
\hline Plantations & June-October & $\mathrm{I}=5.0+0.20(\mathrm{P})$ \\
\hline \multirow{2}{*}{ Agricultural crops (paddy) } & June & 0 \\
\cline { 2 - 4 } & July-August & $\mathrm{I}=1.8+0.10(\mathrm{P})$ \\
\hline
\end{tabular}

\begin{tabular}{|l|l|l|}
\hline \multirow{2}{*}{ Grasslands and scrubs } & September & $\mathrm{I}=2.0+0.18(\mathrm{P})$ \\
\cline { 2 - 3 } & October & 0 \\
\hline & June-September & $\mathrm{I}=3.5+0.18(\mathrm{P})$ \\
\cline { 2 - 3 } & October & $\mathrm{I}=2.5+0.10(\mathrm{P})$ \\
\hline
\end{tabular}

Table 5: Interception loss.

Runoff: Portion of rainfall that flows in the streams after precipitation $[2,8,10,11]$ are (i) surface runoff or direct runoff and (ii) sub surface runoff.

Surface runoff: Portion of water that directly enters into the streams during rainfall, which is estimated based on the empirical $[9,10,11]$ relationships given in equation 3 .

$\mathrm{Q}=\Sigma(\mathrm{Ci} \times \mathrm{PR} \times \mathrm{Ai}) / 1000 \ldots \ldots(3)$

Where, Q: Runoff in cubic meters per month; C: Catchment/Runoff coefficient, depends on land uses as given in Table 6 [36]; PR: Net rainfall in $\mathrm{mm}$; i: Land use type; Ai: Area of Landscape i as square meters.

\begin{tabular}{|l|l|}
\hline Land Use & Catchment Coefficient \\
\hline Urban & 0.85 \\
\hline Agriculture & 0.6 \\
\hline Open lands & 0.7 \\
\hline Evergreen forest & 0.15 \\
\hline Scrub/Grassland & 0.6 \\
\hline Forest Planation & 0.65 \\
\hline Agriculture Plantation & 0.5 \\
\hline Deciduous Forest & 0.15 \\
\hline
\end{tabular}

Table 6: Catchment coefficients.

Infiltration: The portion of water enters the subsurface (vadoze and groundwater zones) during precipitation depending on land cover in the catchment. During field monitoring of streams in the forested catchment, overland flow is noticed in streams only after couple of days rainfall. This means that overland flow in the catchment with vegetation cover happens after the saturation of sub surfaces. The water stored in sub-surfaces will flow laterally towards streams and contributes to stream flow during non-monsoon periods, which are referred as pipe flow (during post monsoon) and base flow (during summer).

Inf=RN-Q.......

Ground water recharge: This is the portion of water that is percolated below the soil stratum (vadoze) after soil gets saturated. Recharge is considered the fraction of infiltrated water that recharges the aquifer after satisfying available water capacity and pipe flow. Krishna Rao equation, (equation 5) [19] was used to determine the ground water recharge.

$$
\mathrm{GWR}=\mathrm{RC} \times(\mathrm{PR}-\mathrm{C}) \times \mathrm{A} \ldots \ldots(5)
$$


Where, GWR: Ground water recharge; RC: Ground water recharge coefficient (Table 7); C: Rainfall Coefficient (Table 7); A: Area of the catchment. The recharge coefficient and the constant vary depending land uses with the annual rainfall.

\begin{tabular}{|l|l|l|}
\hline Annual Rainfall & $\mathbf{R}_{\mathrm{C}}$ & $\mathbf{C}$ \\
\hline 400 to $600 \mathrm{~mm}$ & 0.2 & 400 \\
\hline 600 to $1000 \mathrm{~mm}$ & 0.25 & 400 \\
\hline$>2000 \mathrm{~mm}$ & 0.35 & 600 \\
\hline
\end{tabular}

Table 7: Ground water recharge coefficients.

Sub surface flow (Pipe flow): Part of the infiltrated effective rainfall circulates more or less horizontally (lateral flow) in the superior soil layer and appears at the surface through stream channels is referred as subsurface flow. The presence of a relatively permeable shallow layer favors this flow. Subsurface flows in water bearing formations have a drainage capacity slower than superficial flows, but faster than groundwater flows. Pipe flow is considered to be the fraction of water that remains after infiltrated water satisfies the available water capacities under each soil. Pipe flow is estimated for all the basins as function of infiltration, ground water recharge and pipe flow coefficient, given by equation 6

$$
\mathrm{PF}=(\text { Inf-GWR }) \times \mathrm{KP}
$$

Where, PF: Pipeflow; Inf: Infiltration volume; KP: Pipe flow coefficient [2]

Groundwater discharge: Groundwater discharge or base flow is estimated by multiplying the average specific yield of aquifer under each land use with the recharged water. Specific yield represents the water yielded from water bearing material. In other words, it is the ratio of the volume of water that the material, after being saturated, will yield by gravity to its own volume. Base flow appears after monsoon and receding of pipe-flow. This water generally sustains flow in the rivers during dry seasons. A portion of recharged water flows to the streams as ground water discharge which is dependent on the topography, geology and the land use conditions. Equation 7 defines Ground water discharge as product of specific yield and the portion of ground water recharged.

\section{$\mathrm{GWD}=\mathrm{GWR} \times \mathrm{YS} \ldots \ldots .(7)$}

Where, GWD: Ground water discharge; GWR: Ground water recharge; YS: Specific yield [2].

\section{Estimation of water demand evapotranspiration}

Evaporation is a process where in water is transferred as vapour to the atmosphere. Transpiration is the process by which water is released to the atmosphere from plants through leaves and other parts above ground. Evapotranspiration is the total water lost from different land use due to evaporation from soil, water and transpiration by plants. Some of the important factors that affect the rate of evapotranspiration are: (i) temperature, (ii) wind, (iii) light intensity, (iv) Sun light hours, (v) humidity, (vi) plant characteristics, (vii) land use type and (viii) soil moisture. If sufficient moisture is available to completely meet the needs of vegetation in the catchment, the resulting evapotranspiration is termed as potential evapotranspiration (PET). The real evapotranspiration occurring in specific situation is called as actual evapotranspiration (AET). These evapotranspiration rates from forests are more difficult to describe and estimate than for other vegetation types.

Potential evapotranspiration (PET) was determined using Hargreaves method (Hargreaves [2,36]) an empirical based radiation based equation, which is shown to perform well in humid climates. PET is estimated as $\mathrm{mm}$ using the Hargreaves equation is given by equation 8 .

$\mathrm{PET}=0.0023 \times(\mathrm{RA} / \lambda) \times \sqrt{ }(\mathrm{Tmax}-\mathrm{Tmin}) \times((\mathrm{Tmax}+\mathrm{Tmin}) / 2+17.8)$ .......(8)

Where, RA: Extra-terrestrial radiation $\left(\mathrm{MJ} / \mathrm{m}^{2} /\right.$ day) [36]; Tmax: Maximum temperature [42]; Tmin: Minimum temperature [42]; $\lambda$ : latent heat of vapourisation of water $(2.501 \mathrm{MJ} / \mathrm{kg})$

Actual evapotranspiration is estimated as a product of Potential evapotranspiration (PET) and Evapotranspiration coefficient (KC) (Table 8), given in equation 9. The evapotranspiration coefficient is a function of land use varies with respect to different land use. Table 8 gives the evapotranspiration coefficients for different land use

$\mathrm{AET}=\mathrm{PET} \times \mathrm{KC} \ldots \ldots(9)$

\begin{tabular}{|l|l|}
\hline \multicolumn{1}{|c|}{ Land use } & \multicolumn{1}{c|}{$\mathbf{K}_{\mathrm{C}}$} \\
\hline Built-up & 0.15 \\
\hline Water & 1.05 \\
\hline Open space & 0.3 \\
\hline Evergreen forest & 0.95 \\
\hline Scrub and grassland & 0.8 \\
\hline Forest Plantation & 0.85 \\
\hline Agriculture Plantation & 0.8 \\
\hline Deciduous forest & 0.85 \\
\hline
\end{tabular}

Table 8: Evapotranspiration coefficient.

Note: the crop water requirement was estimated for different crops and different seasons based on land use, assumption is individual crop water requirement and different growth phases (need different quantum of water for their development inclusive of evaporation).

Domestic water demand: Understanding the population dynamics in a region is necessary to quantify and also to predict the domestic water demand. Population census for villages during 2001 and 2011 [24] were considered in order to compute the population of the basin level. Based on the rate of change of population (equation 10), the population for the year 2014 was predicted as given in equation 11 .

$$
\mathrm{r}=(\mathrm{P} 2011 / \mathrm{P} 2001-1) / \mathrm{n} \ldots \ldots(10)
$$

Where, P2001 and P2011 are population for the year 2001 and 2011 respectively; $\mathrm{n}$ is the number of decades which is equal to $1 ; \mathrm{r}$ is the rate of change

$\mathrm{P} 2014=\mathrm{P} 2011 \times(1+\mathrm{n} \times \mathrm{r}) \ldots \ldots(11)$

Where, P2014 is the population for the year 2014; $\mathrm{n}$ is the number of decades which is equal to 0.3 .

Domestic water demand is assessed as the function of water requirement per person per day, population and season. Water required per person includes water required for bathing, washing, 
drinking and other basic needs. Water requirements across various seasons are as depicted in Table 9.

\begin{tabular}{|l|l|}
\hline Season & Water Ipcd \\
\hline Summer & 150 \\
\hline Monsoon & 125 \\
\hline Winter & 135 \\
\hline
\end{tabular}

Table 9: Seasonal water requirement.
Livestock water requirement: Household surveys were conducted with the structured questionnaires to understand the agricultural and horticulture cropping pattern and water needed for various crops in the catchment. Livestock population details were obtained from the district statistics office and water requirement for different animals were quantified based on the household interviews. Table 10 gives the water requirement for various animals.

\begin{tabular}{|l|l|l|l|l|l|l|l|l|l|}
\hline & \multicolumn{7}{|c|}{ Water Requirement in Ipcd (Liters per animal per day) } \\
\hline SeasonlAnimal & Cattle & Buffalo & Sheep & Goat & Pigs & Rabbits & Dogs & Poultry \\
\hline Summer & 100 & 105 & 20 & 22 & 30 & 2 & 10 & 0.35 \\
\hline Monsoon & 70 & 75 & 15 & 15 & 20 & 1 & 6 & 0.25 \\
\hline Winter & 85 & 90 & 18 & 20 & 25 & 1.5 & 8 & 0.3 \\
\hline
\end{tabular}

Table 10: Livestock water requirement.

Crop water requirement: The crop water requirement for various crops was estimated considering their growth phase and details of the cropping pattern in the catchment (based on the data compiled from household surveys and publications such as the district at a glance, department of agriculture). Land use information was used in order to estimate the cropping area under various crops. Figure 12 provides the information of various crop water requirements based on their growth phase as cubic meter per hectare.

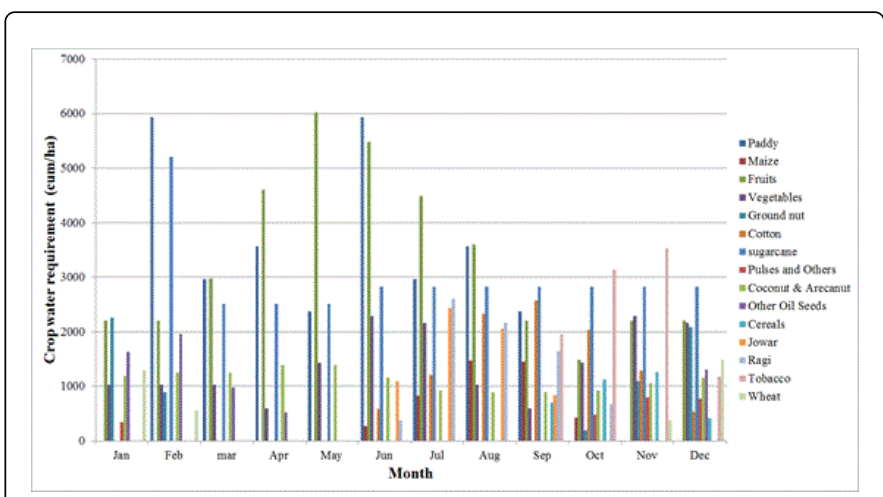

Figure 12: Crop water requirement (as cum per hectare per month).

Evaluating hydrological status: The hydrological status in the catchment is analysed for each month based on the water balance which take into account the water available to that of the demand. The water available in the catchment is function of water in the soil, run off (streams and river) and water available in the water bodies (Lentic water bodies such as lakes, etc.). Water demand in the catchment is estimated as the function of societal demand and terrestrial ecosystem (AET from forested landscape) crop water demand, domestic and livestock demand and the evapotranspiration. The catchment is considered hydrological sufficient, if the water available caters the water demand completely else the deficit catchment, if the water demand is more than the water available in the system.
Quantification of the environmental flow: Ecological investigations include the investigations of fish diversity across seasons. Habitat simulation method [51-56] was adopted to assess flows on basis of quantity and suitability of physical habitat available to target species under different flow regimes. In order to evaluate the natural flow regime [53,54], 18-24 months field monitoring of select streams in Sharavathi river basin and at Hongadahalla and Kadumanehalla (of Yettinaholé catchment) was carried out. This field data was compared with the long term flow measurements data at Hongadahalla and Kadumanehalla [45]. The natural flow that sustains native biota during lean season is accounted as the ecological or environmental flow [57-60] for the respective lotic system. In the current study, hydrologic assessment and investigations on the occurrence of native fish species (with diversity) helped in ascertaining the minimum flow required to sustain the native fish biota.

\section{Results}

\section{Land use analysis}

Land use analysis was carried out using remote sensing data of 2014, for Yettinaholé catchment (a tributary of Gundia River) and results are given in Figure 13 and Table 11. Major portion of the catchment is covered with evergreen forest (45.08\%) followed by agriculture plantations $(29.05 \%)$ and grass lands $(24.06 \%)$. The valleys along the stream are dominated by agriculture lands and horticulture plantations, the hill tops dominated by grass lands, slopes covered with forest cover. The accuracy of the land use classification is $87 \%$ with kappa of 0.82 . Temporal land use in the Gundia river catchment during 2000, 2006, 2010 and 2014 are depicted in Figure 14 and details are provided in Table 12. Results reveal that area under forests has reduced from $70.74 \%$ (in 2000) to $61.15 \%$ (in 2014).

\begin{tabular}{|l|l|}
\hline Land use & Area (\%) \\
\hline Built up & 0.07 \\
\hline Agriculture Plantation & 29.25 \\
\hline
\end{tabular}


Citation: Ramachandra TV, Vinay S, Bharath HA (2016) Environmental Flow Assessment in a Lotic Ecosystem of Central Western Ghats, India. Hydrol Current Res 7: 248. doi:10.4172/2157-7587.1000248

Page 9 of 14

\begin{tabular}{|l|l|}
\hline Evergreen & 45.08 \\
\hline Forest Plantation & 0.001 \\
\hline Water & 0.002 \\
\hline Open land & 0.91 \\
\hline Agriculture & 0.62 \\
\hline Grassland & 24.06 \\
\hline
\end{tabular}

Table 11: Land use in Yettinaholé catchment.

The region receives annual rainfall ranging from $3000 \mathrm{~mm}$ to 4500 $\mathrm{mm}$. Variability of rainfall was assessed based on 11 rain gauge stations in the catchment and is given in Figure 15.

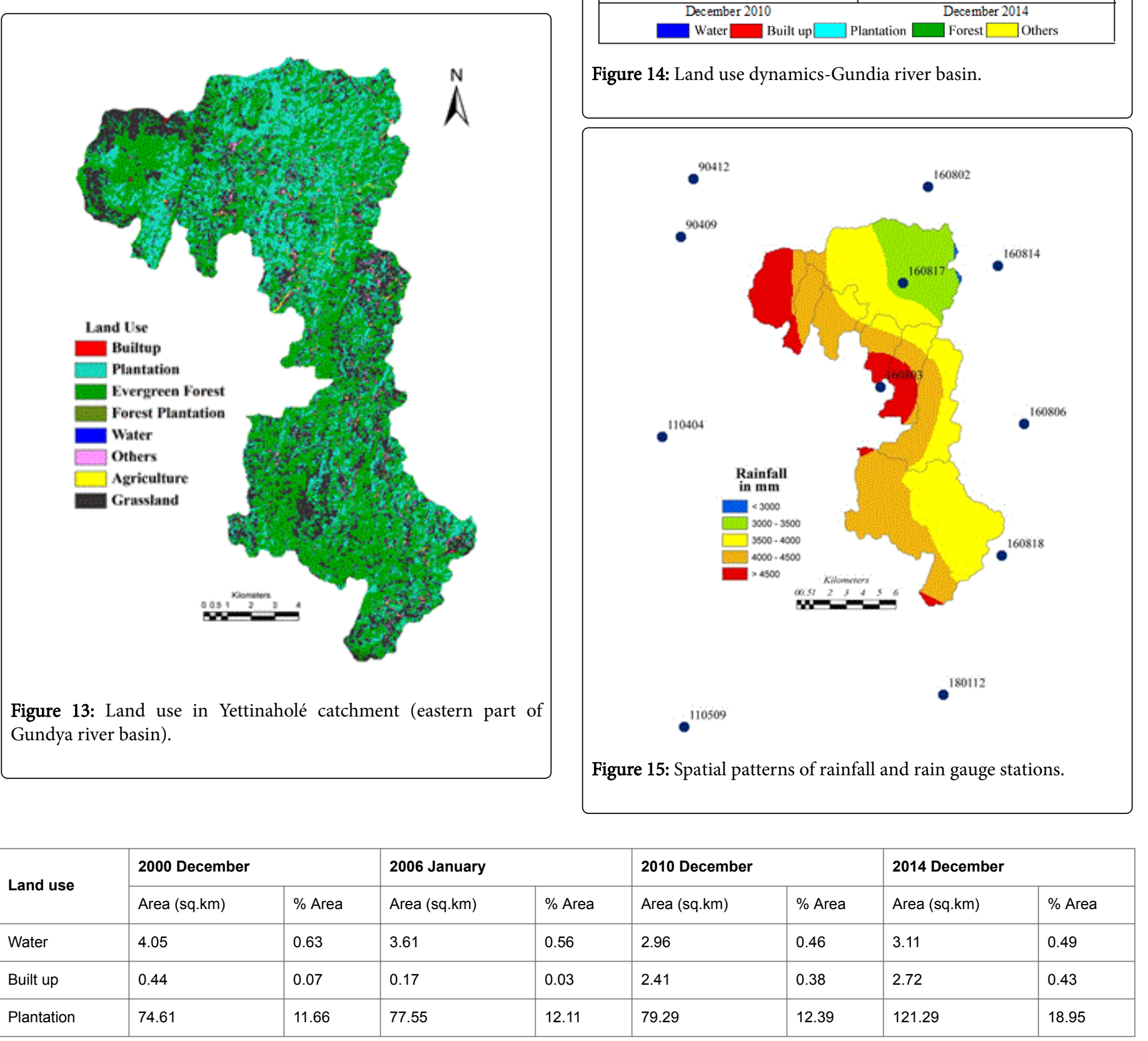

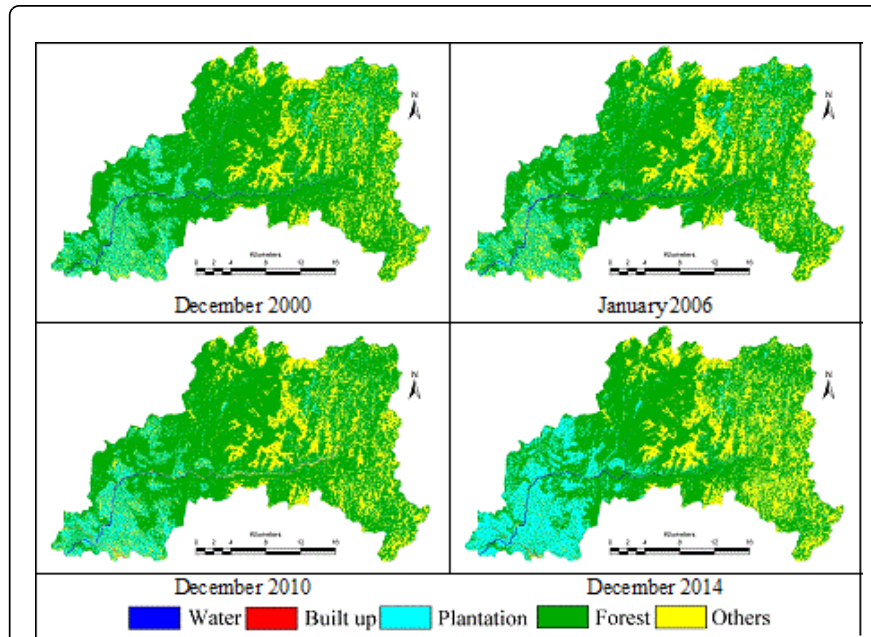

Figure 14: Land use dynamics-Gundia river basin.

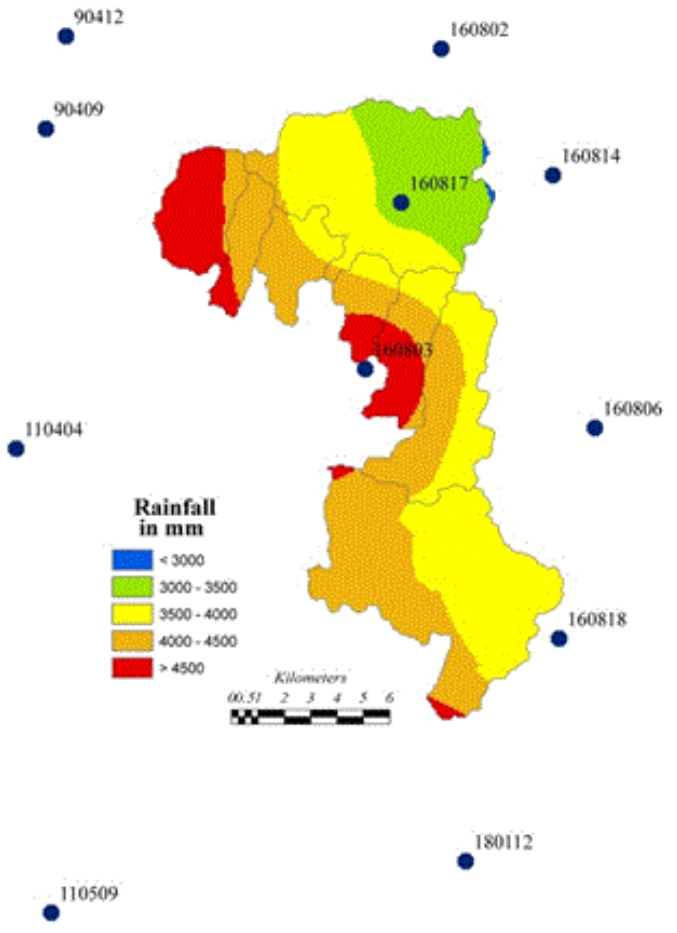




\begin{tabular}{|l|l|l|l|l|l|l|l|l|}
\hline Forest & 452.8 & 70.74 & 443.36 & 69.26 & 443.27 & 69.25 & 391.43 & 61.15 \\
\hline Others & 108.22 & 16.91 & 115.44 & 18.03 & 112.18 & 17.53 & 121.56 & 18.99 \\
\hline
\end{tabular}

Table 12: Land use dynamics - Gundia River basin.

Figure 16 provides the annual variability of hydrological parameters for understanding the hydrological regime. Gross rainfall, estimated as product of catchment area and rainfall. The gross rainfall varies from 33232 kilo.cum (in Kadumane holé 2 and Yettinaholé 2) and over 2000000 kilo.cum (in Yettinaholé and Hongada halla catchments). Portion of the water doesn't reach the earth surface, but is intercepted by the earth features namely the tree canopy, building tops, pavements etc., which gets evaporated. Runoff in the basin is estimated as a function of catchment characteristics along with rainfall. Yettinholé, catchment is covered predominantly by evergreen forests, has aided in recharging groundwater zone and sub surfaces. Infiltration of significant amount of precipitation to underlying layers, has reduced the overland flow and thus retarded the flash floods. The infiltration of water to sub-surface takes place during monsoon, and overland flow (surface runoff) happens during the monsoon (rainfall $>50 \mathrm{~mm}$ per month) and quantity depends on the catchment characteristics namely land use/land cover in the catchment, soil porosity, texture, presence of organic matter (leave debris, decayed matter etc.). The portion of water percolates through the sub surfaces and thus recharges ground water resources. Water stored in vadoze zone (sub-surface) and groundwater zone moves laterally to streams with cessation of rain. Forests in the catchment have played a prominent role in maintaining stream flow, water holding capacity of soil, ground water, which also plays a pivotal role in catering the ecological and environmental demand of water. Sub basin wise yields are listed in Table 13; the surface runoff during the monsoon is estimated to be 9.55 TMC.

\begin{tabular}{|l|c|c|c|}
\hline \multicolumn{1}{|c|}{ Sub basin } & Average Annual Rainfall mm & Gross Rainfall TMC & Runoff yield as TMC \\
\hline Yettina hole & 3539.73 & 5.98 & 2.62 \\
\hline Yettina holé T2 & 4311.44 & 1.23 & 0.58 \\
\hline Yettina holé T1 & 4109.99 & 1.33 & 0.57 \\
\hline Kadumane holé 2 & 4364.85 & 1.2 & 0.53 \\
\hline Kadumane holé 1 & 4725.54 & 1.79 & 0.7 \\
\hline Hongadahalla & 4000.77 & 6.7 & 2.68 \\
\hline Keri holé & 4013.09 & 2.69 & 1.17 \\
\hline Yettina holé lower reach & 4385.25 & 1.81 & 0.69 \\
\hline \multicolumn{2}{|c|}{ GROSS Yield (TMC) } & & 9.55 \\
\hline
\end{tabular}

Table 13: Catchment yield.

Evapotranspiration in the catchment depends on the land use, solar radiation, variations in temperature, precipitation, etc. Potential evapotranspiration was estimated using Hargreaves method. PET indicates the maximum possible water that can evaporate, PET varies between $160 \mathrm{~mm} / \mathrm{month}$ (March) to $85 \mathrm{~mm} / \mathrm{month}$ (monsoon season). Considering the various land use characteristics in the catchments, actual evapotranspiration was estimated in the catchments show variation of $40 \mathrm{~mm} / \mathrm{month}$ (monsoon) to $120 \mathrm{~mm} / \mathrm{month}$ (March).

Crop water demand was calculated in each catchment based on cropping pattern, area under each crop, and water required across the growth phases of the crops, which were compiled from various literatures (local, national and international) and discussion with the public regarding cropping practices and experiences. Table 9 and Figure 12, details season-wise crop water requirements and growth phases. The agricultural water demand of 2.6 TMC in the catchments is for horticultural and paddy cultivation. Livestock water demand given in Table 10 was estimated based on the livestock population (compiled from District at a glance of Hassan 2012-13).
Census data for the year 2001 and 2011 with the decadal rate of change in population was used compute the population for 2014 and water demand. Population for the year 2014 was estimated as 16156 persons. Catchment had a population of 17005 (in 2001), which decreased to 16345 (in 2011) at a decadal decline of $3.88 \%$. The population density in the catchments varies from 33 persons per sq.km (in Keriholé) to about 150 persons per sq.km (Yettinaholé lower reach).

Ecological Flow Assessment: Flow measurements during the study period at two basins namely Hongadahalla and Kadumaneholé of Yettinaholé namely and based on the long term monitoring data [45] is given in Figures 16 and 17 respectively. This illustrates that flow during the lean season is about $10 \%$ of the annual flow, which is lower than the minimum flow requirement to sustain the ecosystem services in the water body.

Monthly monitoring of select streams in Sharavathi River basin over 24 months (covering all seasons) revealed the linkages of fish diversity with the duration of water flow in the respective stream. Table 14 lists the fish diversity across monitored streams. The current assessment confirm the requirement of 24 to $30 \%$ of annual flow during lean 
Citation: Ramachandra TV, Vinay S, Bharath HA (2016) Environmental Flow Assessment in a Lotic Ecosystem of Central Western Ghats, India. Hydrol Current Res 7: 248. doi:10.4172/2157-7587.1000248

Page 11 of 14

seasons to sustain the native fish diversity of endemic species [46,47]. Based on this, the ecological flow in Yettinaholé catchment (during the lean seasons) is $2.8 \mathrm{TMC}$.

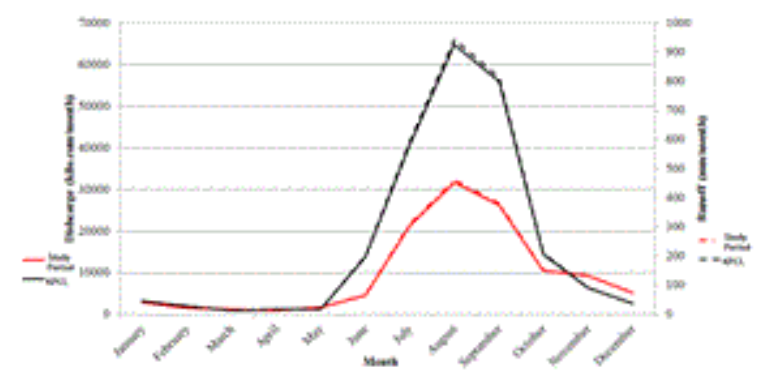

Figure 16: Hongadahalla.

\begin{tabular}{|c|c|c|c|c|c|c|c|c|c|c|}
\hline \multirow{2}{*}{ Fishes (Scientific Name) } & \multicolumn{10}{|c|}{ Hill streams } \\
\hline & $\begin{array}{l}\text { Huruli } \\
\text { River }\end{array}$ & $\begin{array}{l}\text { Nagodi } \\
\text { River }\end{array}$ & $\begin{array}{l}\text { Birer } \\
\text { River }\end{array}$ & $\begin{array}{l}\text { Yenne } \\
\text { River }\end{array}$ & $\begin{array}{l}\text { Kouthi } \\
\text { Stream }\end{array}$ & Sharavathi & Hilkunji & $\begin{array}{l}\text { Sharmanavath } \\
\mathrm{i}\end{array}$ & Haridravathi & Nandihole \\
\hline \multicolumn{11}{|l|}{ Amblyphyrngodon mola } \\
\hline Aplocheilus lineatus & * & * & * & * & * & * & * & * & & \\
\hline Barilius canarensis & & & * & & * & & & & & \\
\hline \multicolumn{11}{|l|}{ Catla catla } \\
\hline Chanda nama & * & & & & & & * & & & \\
\hline Channa marulius & & & & & & * & & & & \\
\hline Cirhina fulungee & & & & & & * & & * & & \\
\hline \multicolumn{11}{|l|}{ Cirhina mrigala } \\
\hline Cirrhinus reba & & & & & & & & * & & \\
\hline \multicolumn{11}{|l|}{ Clarius byatracus } \\
\hline Cyprinus carpio & & & & & & * & & & & \\
\hline Danio aequipinnatus & * & * & * & * & * & * & * & * & * & * \\
\hline Garra gotyla stenorynchus & * & & & & & * & & * & & * \\
\hline \multicolumn{11}{|l|}{ Glossogobius giurus } \\
\hline \multicolumn{11}{|l|}{ Heteropneustis fossilis } \\
\hline \multicolumn{11}{|l|}{ Labeo fimbriatus } \\
\hline Labeo rohita & & & & & & * & & & & \\
\hline $\begin{array}{l}\text { Lepidocephalichthys } \\
\text { thermalis }\end{array}$ & & & * & & * & & & & & \\
\hline Mastacembalus arnatus & & & & & & * & & & & \\
\hline Mystus cavesius & * & & & & & & & & & \\
\hline Mystus keletius & * & & & & & & & & & \\
\hline Mystus malabaricus & * & & & & & & & & & \\
\hline
\end{tabular}

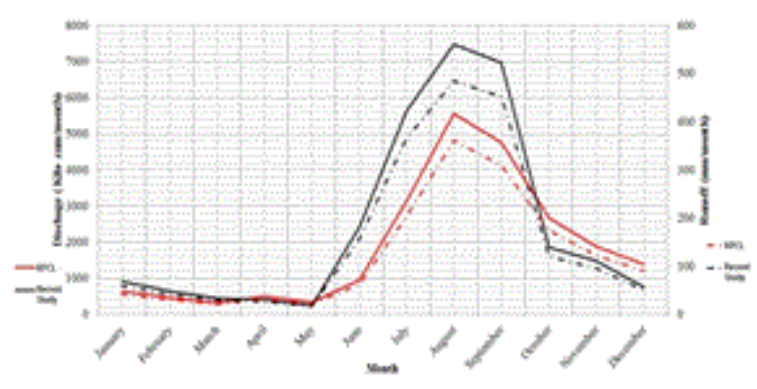

Figure 17: Kadumaneholé. 
Citation: Ramachandra TV, Vinay S, Bharath HA (2016) Environmental Flow Assessment in a Lotic Ecosystem of Central Western Ghats, India. Hydrol Current Res 7: 248. doi:10.4172/2157-7587.1000248

\begin{tabular}{|c|c|c|c|c|c|c|c|c|c|}
\hline Namacheilus rueppelli & & * & * & & & & & & \\
\hline Ompok bimaculatus & & & & & & * & & & \\
\hline \multicolumn{10}{|l|}{ Ompok sp. } \\
\hline \multicolumn{10}{|c|}{ Oreochromis mossambica } \\
\hline Pseudambasis ranga & * & & & & & & & & \\
\hline $\begin{array}{l}\text { Pseudeutropius } \\
\text { atherenoides }\end{array}$ & * & & & & & & & & \\
\hline Puntius arulius & & & & & * & & & & \\
\hline \multicolumn{10}{|l|}{ Puntius dorsalis } \\
\hline Puntius fasciatus & * & * & * & * & * & & & & \\
\hline Puntius filamentosis & & & & * & * & & & & \\
\hline \multicolumn{10}{|l|}{ Puntius kolus } \\
\hline \multicolumn{10}{|l|}{ Puntius narayani } \\
\hline \multicolumn{10}{|l|}{ Puntius parrah } \\
\hline \multicolumn{10}{|l|}{ Puntius ticto } \\
\hline Rasbora daniconius & * & * & * & * & * & * & * & * & * \\
\hline Salmostoma boopis & & & & & & * & * & * & \\
\hline
\end{tabular}

Table 14: Fish diversity in select streams of Sharavathi River basin.

\begin{tabular}{|l|l|l|}
\hline & Description & Quantity \\
\hline 1 & Gross Area & $179.68 \mathrm{sq} \cdot \mathrm{km}$ \\
\hline 2 & Average Annual Rainfall & $3500-4500 \mathrm{~mm}$ \\
\hline 3 & Water Yield in Yettinaholé catchment & $9.55 \mathrm{TMC}$ \\
\hline 4 & Ground Water Recharge & 0.49 TMC \\
\hline 5 & Evapotranspiration & $3.16 \mathrm{TMC}$ \\
\hline 6 & Irrigation Water Requirement & $2.64 \mathrm{TMC}$ \\
\hline 7 & Domestic Water Requirement & $0.03 \mathrm{TMC}$ \\
\hline 8 & Livestock Water Requirement & $0.01 \mathrm{TMC}$ \\
\hline 9 & Total Water Demand (anthropogenic) & $5.84 \mathrm{TMC}$ \\
\hline 10 & Ecological or environmental flow & $2.8 \mathrm{TMC}$ \\
\hline
\end{tabular}

barren area (4 months). The available water in Yettinaholé catchment is sufficient to cater the existing water demand (social, ecological and environmental) throughout the year.

Table 15: Hydrological assessment in Yettinaholé catchment.

The water demand and availability are listed in Table 15 and Figure 18 depicts the spatial variability of resources. Total water demand (5.84 TMC of water) across the catchments (accounting anthropogenic and evapo-transpiration of terrestrial ecosystems) was obtained as a function of evaporation, livestock, and domestic and agriculture demands. Availability of water in the catchment was assessed as a function of runoff during all seasons. The assessment showed that most streams in the forested catchment are perennial compared to steams in the catchment predominantly covered with monoculture plantations (6-9 months) or the streams in catchment dominated by open area or 


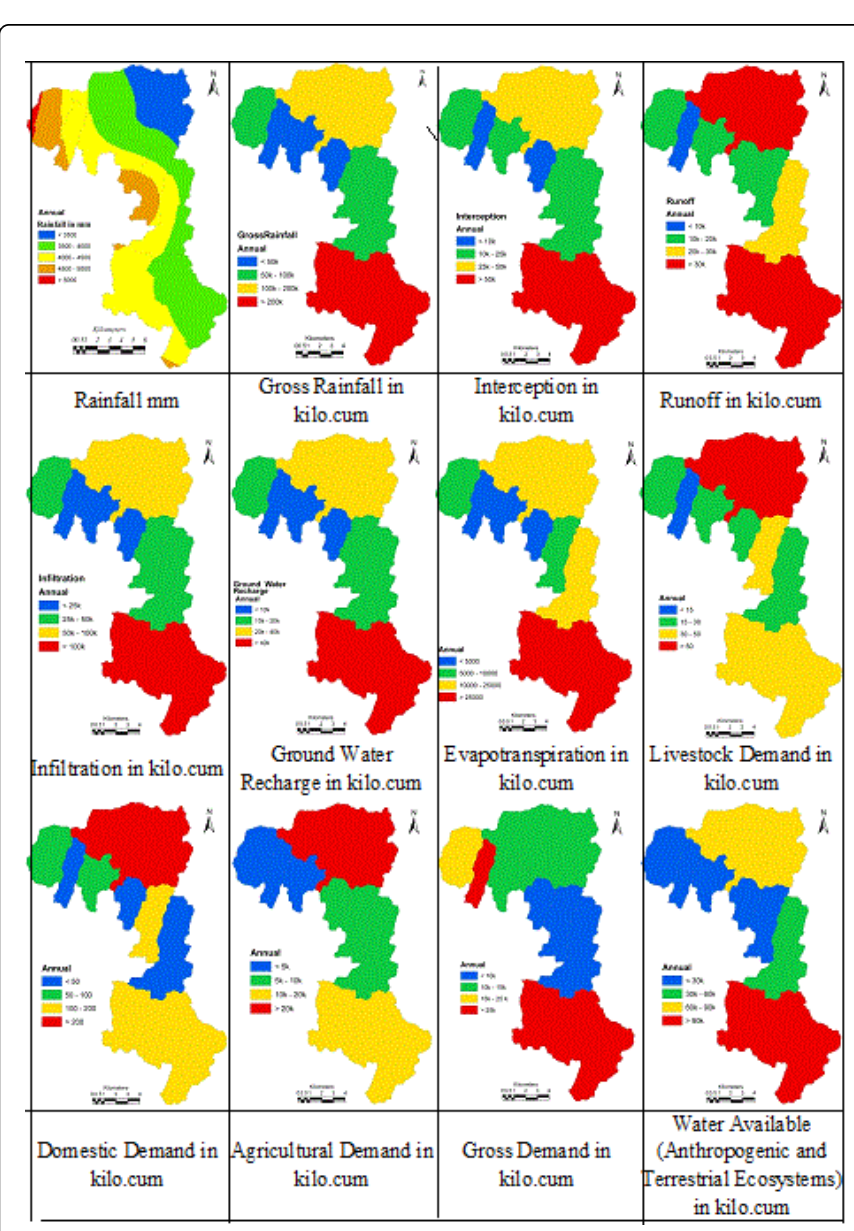

Figure 18: Hydrologic assessment in Yettinaholé catchment.

\section{Conclusion}

Yettinaholé River is currently catering to the anthropogenic and ecological water needs in the catchment. Higher discharge of water during monsoon has helped in the transport of nutrients, silt, etc., which has helped in sustaining the riparian's vegetation and aquatic life apart from meeting the anthropogenic demand (for horticulture, agriculture etc.). Many streams of Yettinaholé are perennial, which has helped in sustaining the rich and diverse aquatic life apart from sustaining horticultural, agricultural activities (3 crops per year) and fishery.

Hydrological yield computation shows the water yield in the catchment is about 9.5 TMC, About 5.84 TMC is required for domestic purposes including agriculture, horticulture and livestock rearing and the quantum of water required to sustain fish life in the streams is about 2 TMC. This highlights that water available in the catchment is sufficient to sustain the current ecological and anthropogenic (agricultural, horticultural) demand. Alterations in the catchment integrity (land cover) or water diversions would result in the variation in the natural flow regime affecting the biodiversity of riparian's and aquatic habitats and more importantly people's livelihood who are dependent on fisheries, etc. in the downstream. In this contyext, The federal government's plan to divert Yettinaholé River water to the dry arid regions in Karnataka is neither technically feasible, economically viable nor ecologically sound apart from depriving the anthropogenic demand in the Yettinaholé River catchment. The sustainable option to meet the water requirements in arid regions is through (i) decentralized water harvesting (through tanks, ponds, lakes, etc.), (ii) rejuvenation or restoration of existing lakes/ponds, (iii) reuse of treated waste water, (iv) recharging groundwater resources, (v) planting native species of plants in the catchment, (vi) implementation of soil and water conservation through micro-watershed approaches.

\section{Acknowledgements}

We acknowledge the financial and infrastructure support from (i) the ENVIS division, the Ministry of Environment, Forests and Climate Change, Government of India, (ii) the NRDMS division, Ministry of Science and Technology, Government of India and (iii) Indian Institute of Science. We thank all stakeholders of Yettinaholé River and also dry arid regions for actively taking part in the scientific discussions and cooperation during field data compilation.

\section{References}

1. Ramachandra TV, Chandran MDS, Prakash SS, Rao GR, Vinay S (2013) Kumaradhara River Basin, Karnataka Western Ghats: Need for conservation and sustainable use. ENVIS Technical Report 54, Environmental Information System (ENVIS), Centre for Ecological Sciences, Indian Institute of Science, Bangalore, India.

2. Ramachandra TV, Chandran MDS, Joshi NV, Vinay S, Bharath HA, et al. (2013) Carrying capacity of river basins considering ecological and social demands. ENVIS Technical Report No. 66, Environmental Information System (ENVIS), Centre for Ecological Sciences, Indian Institute of Science, Bangalore, India.

3. Gunnell Y, Radhakrishna BP (2001) Sahyādri - The Great Escarpment of Indian Subcontinent. Patters of Landscape development in Western Ghats, Geological Society of India, p: 47.

4. Daniels RJR, Jayshree V (2008) Western Ghats - Biodiversity, People, Conservation, Rupa and Co. ISBN: 978-81-291-1310-8.

5. Gururaja KV, Sreekantha S, Rao A, Mukri VD, Ramachandra TV (2007) Biodiversity and Ecological Significance of Gundia River Catchment. CES Technical Report 117, Centre for Ecological Sciences, Indian Institute of Science, Bangalore, India.

6. Sreekantha K, Chandran MDS, Mesta DK, Rao GR, Gururaja KV, et al. (2007) Fish diversity in relation to landscape and vegetation in central Western Ghats, India. Current Science 92: 1592-1603.

7. Ramachandra TV, Chandran MDS, Bhat HR, Dudani S, Rao GR, et al. (2010) Biodiversity, Ecology and Socio-Economic Aspects of Gundia River Basin in the context of proposed Mega Hydro Electric Power Project. CES Technical Report 122, Centre for Ecological Sciences, Indian Institute of Science, Bangalore, India.

8. Vinay S, Bharath S, Bharath HA, Ramachandra TV (2013) Hydrologic Model with Landscape Dynamics for Drought Monitoring. In proceeding of: Joint International Workshop of ISPRS WG VIII/1 and WG IV/4 on Geospatial Data for Disaster and Risk Reduction, Hyderabad, November 21-22.

9. Ramachandra TV, Nupur N, Vinay S, Bharath HA (2014) Modeling Hydrologic regime of Lakshmanatirtha watershed, Cauvery River. Conference proceedings of IEEE, GHTC-SAS 2014, Trivandrum, September 26-27.

10. Raghunath HM (1985) Hydrology. Wiley Eastern Limited, ISBN: 0-85226-746-0.

11. Subramanya K (2005) Engineering Hydrology. Tata McGraw-Hill Publishing Company Limited, New Delhi, 2nd edn. ISBN: 0-07-462449-8.

12. Ray R, Chandran MDS, Ramachandra TV (2015) Hydrological importance of sacred forest fragments in Central Western Ghats of India. Tropical Ecology 56: 87-99. 
13. Ramachandra TV, Chandran MDS, Vinay S, Sudarshan B, Vishnu DM, et al. (2016) Sacred Groves (Kan forests) of Sagara Taluk, Shimoga District, Sahyadri Conservation Series: 54, ENVIS Technical Report 102, Environmental Information System (ENVIS), Centre for Ecological Sciences, Indian Institute of Science, Bangalore, India.

14. Mesta PN, Bharath S, Chandran MDS, Rajan KS, Ramachandra TV (2014) Inventorying, Mapping and Monitoring of Mangroves towards Sustainable Management of West Coast, India. J Geophysics Remote Sensing 3: 130-138.

15. Calder IR, Newson MD (1979) Land use and upland water resources in Britain; a strategic look. Water Resources Bulletin 16: 1628-1639.

16. Ramachandra TV, Nupur N, Vinay S, Bharath HA (2014) Modeling Hydrologic regime of Lakshmanatirtha watershed, Cauvery River, India Conference proceedings of IEEE, GHTC-SAS 2014, Trivandrum, September 26-27.

17. Batelaan O, Smedt FD (2007) GIS-based recharge estimation by coupling surface subsurface water balances. Journal of Hydrology 337: 337-355.

18. Amitha K (2000) Estimation of natural ground water recharge. LAKE 2000: National Conference, Indian Institute of Science, Bangalore, November 27-29.

19. Mahima B, Nayak VN, Chandran MDS, Ramachandra TV (2012) Impact of Hydroelectric Dams on Fisheries in the Sharavathi Estuary of Uttara Kannada District, South-West India, LAKE 2012: National Conference, MG University Kerala, November 6-8.

20. Ramachandra TV, Chandran MDS, Joshi NV, Rajinikanth R, Kumar R (2012) Water, Soil, and Sediment Characterisation: Sharavathi River Basin, Western Ghats, Sahyadri Conservation Series: 54, ENVIS Technical Report 21, Environmental Information System (ENVIS), Centre for Ecological Sciences, Indian Institute of Science, Bangalore, India.

21. Karthik B, Ramachndra TV (2006) Water Quality Status of Sharavathi River basin, Western Ghats. ENVIS Technical Report 23, Environmental Information System (ENVIS), Centre for Ecological Sciences, Indian Institute of Science, Bangalore, India.

22. Ramachandra TV, Chandran MDS, Joshi NV, Kumar S (2012) Conservation of Endangered Fauna in Sharavathi River Basin. Central Western Ghats, ENVIS Technical Report 22, Environmental Information System (ENVIS), Centre for Ecological Sciences, Indian Institute of Science, Bangalore, India.

23. Census of India 2001 and 2011 (2016).

24. Hassan District Statistics (2016) General Information.

25. Directorate of Economics and Statistics (2015) Government of Karnataka, Karnataka.

26. World Clim-Global Climate Data (2016) World Clim.

27. United States Geological Survey (2016) Science for a Changing World.

28. Ministry of Earth Science (2016) Indian Meteorological Department, Pune.

29. National Food Security Mission

30. Krishiseva Agriculture Information Hub (2016) Crop Calendar.

31. Agropedia Web Portal (2016) Openagri.

32. Department of Agriculture (2016) Government of Karnataka.

33. iKisan Agriculture Portal (2016).

34. Indian Agriculture Research Institute (2016) ICAR.

35. Food and Agriculture Organization of the United Nations (2016).

36. Climate Research Unit (2016) University of East Anglia, UK.
37. National Aeronautics and Space Administration (2016) Global Climate Change.

38. Hassan District at a Glance.

39. Indian Geo-Platform of ISRO (2016) Bhuvan, NRSC.

40. French Institute of Pondicherry (2016) Ecology, Geomatics.

41. India Biodiversity Portal (2016) The Western Ghats.

42. A Setu Himachalam (2016) Survey of India.

43. Detailed Project Report, Yettinaholé Project (2013) Karnataka Neeravari Nigam Limited, Bangalore.

44. Ramachandra TV (2010) Ecology, Biodiversity and Hydrology: Linkages. LAKE 2010: Indian Institute of Science, Bangalore.

45. Sreekantha K, Ramachandra TV (2005) Fish diversity in Linganamakki reservoir and Sharavathi River. Ecology, Environment and Conservation 11: 337-348.

46. Ramachandra TV, Bharath S, Bharath HA (2014) Spatio-temporal dynamics along the terrain gradient of diverse landscape. Journal of Environmental Engineering and Landscape Management 22: 50-63.

47. Ramachandra TV, Bharath S, Bharath HA (2012) Peri-Urban to Urban Landscape Patterns Elucidation through Spatial Metrics. International Journal of Engineering Research and Development 2: 58-81.

48. Tropical Rainfall Measuring Mission (TRMM) NASA.

49. Xu CY, Singh VP (2000) Evaluation and generalization of radiation-based methods for calculating evaporation. Hydrological processes 14: 339-349.

50. Xu C, Singh Y (2001) Evaluation and generalization of temperature-based methods for calculating evaporation. Hydrological processes 15: 305-319.

51. Jain SK (2012) Assessment of environmental flow requirements. Hydrological processes 26: 3472-3476.

52. Jain SK (2015) Assessment of environmental flow requirements for hydropower projects in India. Current science 108: 1815-1825.

53. Tharme RE (2003) A Global Perspective on Environmental Flow Assessment: Emerging Trends in the development and application of Environmental Flow methodologies for rivers. River Research and Applications 19: 397-441.

54. King JM, Tharme RE, De Villiers MS (2008) Environmental Flow assessments for rivers: manual for the building block methodology. Water Research Commission Report TT354/08, Freshwater Research Unit, University of Cape Town.

55. The Brisbane Declaration (2007) 10th International River symposium and International Environmental Flows Conference. 3-6 September 2007, Brisbane, Australia

56. Acreman MC, Ferguson AJD (2009) Environmental flows and the European Water Framework Directive. Freshwater Biology 55: 32-48.

57. Chen H, Zhao YW (2011) Evaluating the environmental flows of China's Wolonghu wetland and land use changes using a hydrological model, a water balance model, and remote sensing. Ecological Modelling 222: 53-260.

58. Gupta DA (2008) Implication of environmental flows in river basin management. Physics and Chemistry of the Earth 33: 298-303.

59. Hughes HA (2001) Providing hydrological information and data analysis tools for the determination of ecological instream flow requirements for South African rivers. Journal of Hydrology 241: 140-151.

60. Sreekantha K, Gururaja KV, Ramadevi K, Indra TJ, Ramacahndra TV (2006) Two Species of Fishes of the Genus Schistura McClelland (Cypriniformes: Balitoridae) from Western Ghats, India. Zoos' Print Journal 21: 2211-2221. 